Ann. Biol. anim. Bioch. Biophys., 1978, 18 (4), 883-891.

\title{
Postovulatory changes in the theca folliculi of the trout
}

\author{
by D. SZÖLLÖSI, B. JALABERT, B. BRETON \\ Laboratoire de Physiologie des Poissons, I. N. R. A. \\ 78350 jouy en Josas, France.
}

\begin{abstract}
Summary. At time of ovulation the cells composing the theca folliculi of trout are morphologically smooth muscle like. The physiological behaviour of this tissue confirms its smooth muscle nature. Following ovulation a further cellular transformation and differentiation takes place : within 12-24 hrs after ovulation the theca cells start phagocytozing the adjacent collagen. Bundles of collagen are partially surrounded at first by cellular processes of the thecal cells while finally small bundles of collagen are interiorized. The number of collagen fibers per phagocytotic vesicle varies from one to many. The bundles can be recognized morphologically until $72 \mathrm{hrs}$ after ovulation after which time they become indistinct, indicating a possible hydrolysis. Tests with the « Api-zim » test system demonstrate the presence of a number of lytic enzymes in freeze-thawed post-ovulatory ovarian tissue, in support of the morphological observations.
\end{abstract}

The contraction of the cellular components of the theca results in the expulsion of the oocyte, that is ovulation (Jalabert and Szöllösi, 1975). The theca folliculi behaves physiologically like smooth muscle whose contraction can be evoked in vitro in isolated follicles by the addition of prostaglandin $F_{2} \alpha$. The presence of smooth muscle (or smooth muscle-like cells) as an important component of the theca has been reported for several vertebrafe classes (mammals-see Amsterdam ef al., 1976 ; fishSzöllösi and Jalabert, 1974 ; amphibian-Larsen ef al., 1977). The post-ovulatory structure of the ovary however, was not studied thus far systematically in lower vertebrates. We can report here that the smooth muscle cells become phagocytotically active few hours after ovulation and that these cells incorporate and break down the collagen fiber framework of the theca.

\section{Materials and methods.}

Female trout, Salmo gairdneri, of reproductive age (3-4 years old) were controlled for ovulation daily during the spawning period, from November to February. When ovulation was observed females were stripped to remove all free oocytes. The ovaries were then either removed and spent follicles isolated and fixed immediately or only 12-148 hrs after ovulation. Individual follicles were also fixed after in vitro induction of ovulation (Jalabert and Szöllösi, 1975). The fixative employed was a 2.5 p. 100 
glutaraldehyde, 0.5 p. 100 paraformaldehyde solution in $0.15 \mathrm{M}$ cacodylate buffer at $\mathrm{pH} 7.2$ containing 0.1 p. 100 potassium ferricyanid (Elbers et al., 1965).

The presence of some lytic enzymes in the coelomic fluid recovered within $24 \mathrm{hrs}$ after ovulation was investigated by the « Api-zym 》 test system (Monget, 1975). The collagenase activity in the post-ovulatory ovarian tissue was also controlled (we are very thankful to Dr. Wahl, NIH who kindly analysed our material for collagenase activity according to Nagai ef al., 1966). For these tests the ovaries were perfused by trout balanced salt solution (Jalabert, 1978) immediately after sacrifying the animal to remove the potentially present collagenase inhibitor offen found in blood plasma. The ovaries were then frozen thawed three times. Ovarian fragments were removed by filtration through three layers of cheezecloth. The so produced furbid solution was centrifuged at 1200 r.p.m. to remove cellular debries. The supernatant was slightly yellow and clear, transparent solution; it was dialysed against several changes of $30 \mu \mathrm{M}$ Tris- $\mathrm{HCl}(\mathrm{pH} 7.5)$ buffer for three days at $4^{\circ} \mathrm{C}$ and deep froozen until lyophilisation. The powder obtained was stored until analysis.

Excised post-ovulatory follicles were studied for proteolytic activity on fixed gelatin or collagen membranes (Gaddum and Blandau, 1970 ; Owers and Blandau, 1971). The follicles were blotted dry and placed on the protein membranes and moistened either in a saline-citrate buffer $\mathrm{pH} 4.2$ or in saline-veronal acetate buffer $\mathrm{pH} 7.2$. Coverslips were placed on such preparations and sealed by mineral oil to protect them from drying. These preparations were incubated at $25^{\circ} \mathrm{C}$ for $4 \mathrm{hrs}$. At both $\mathrm{pH}$ levels $0.001 \mathrm{M}$ EDTA was added to some slides.

\section{Results.}

The theca ovarii of the pre-ovulatory trout ovary is constituted of alternating layers of flattened smooth muscle cells and collagen fibers (fig. 1, 2). The basal lamina towards the follicular cells is very thick, measuring $90-100 \mathrm{~nm}$ and represents a convenient marker. The outline of the cells composing the theca is usually smooth with several pinotcytotic vesicles. The cytoplasmic microfilaments of $70-80 \AA$ in diameter represents the most characteristic structural component of these cells (fig. 2). Occasional dense bodies are also seen.

Because the females were tested only once dayly for ovulation the samples representing the earliest times (2-4 hrs) after ovulation have been taken following in vitro induction of ovulation. The images are identical under the two conditions and no further mention will be made later of the conditions from which the follicles were taken. The intracellular filaments, the most stricking cellular marker of thecal cells,

FIG. 1. - Adjacent to the thick basal lamina, (BL) layers of the smooth muscle-like cells (m) of the theca alternate with layers of collogen (c). Cell organelles are limifed to a small cytoplasmic islet at the nuclear poles. The rest of the cytoplasm is occupied by thin filaments. $\times 15000$.

FIG. 2. - Thin filaments, measuring 7-8 $\mathrm{nm}$ in diometer occupy the cytoplasm of the smooth muscle-like cells. Numerous pinocytotic vesicles are close and in apparent association with the plasma membrane. $\times 60000$. 

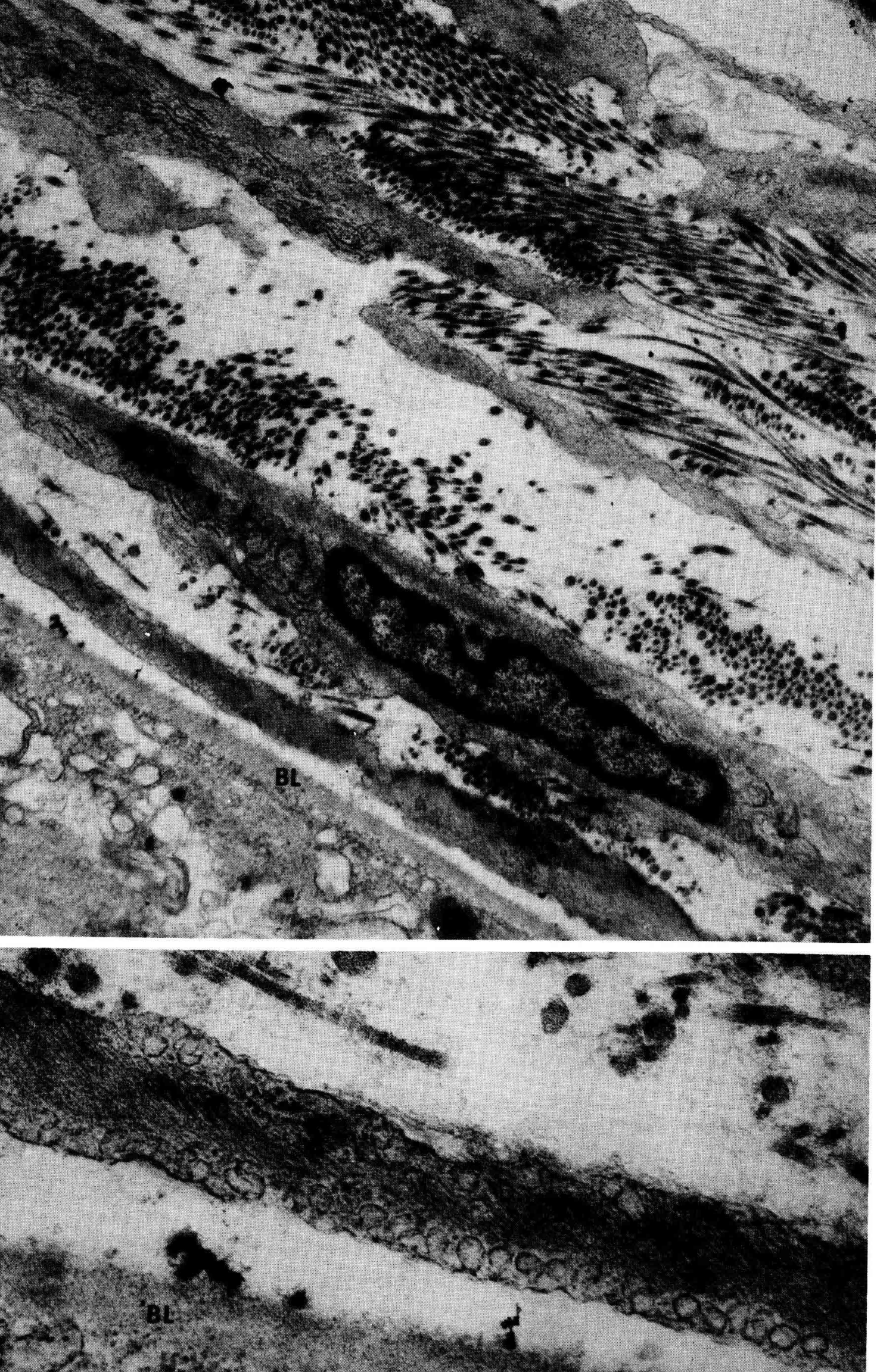
are unaltered after ovulation. The basal lamina towards the follicular cells becomes very tortous and on many places the cell to basal lamina contact is not retained ; buckles of the basal lamina are formed. No firm attachment must thus exist between it and the cells on either side (fig. 3). The cell shape and outline has drastically changed, however. The cells become stellate with many, slender cell processes penetrating the surrounding connective tissue space (fig. 4). The cell processes seem to surround and isolate bundles of collagen fibers consisting of varrying but always large numbers. In the earliest samples taken after ovulation only occasional phagocytotic vesicles are seen containing a few collagen fibers (fig. 5). In specimen taken 24 hrs after ovulation the number of phagocytic vesicles per cell has greatly increased; the size of the vesicles may be very uniform in which one to six collagen fibers are isolated, but larger vesicles may be found next to the small ones. In the cytoplasm many smooth walled, clear, small vesicles are seen, a component usually observed in smooth muscle cells. These vesicles are often in close proximity of the phagocytotic vesicles and occasionally even fusion between the two can be seen (fig. 6); the small vesicles thus may be primary lysosomes. The Golgi element is not well developed. It is always small, localized in small cytoplasmic islands close to the nuclear poles free of the small filaments occupying the major portion of the cytoplasm. In most sections the incorporated collagen fibers are obliquely or cross sectioned. In a few, rare cases a longitudinally cut fiber can be followed for several microns; the phagocytotic vesicles are thus very long.

When longer time interval was permitted to ellapse after ovulation the cell appears to be riddled by phagocytitic vesicles which make neorly contact with each other, leaving only a small cytoplasmic strand between the individual vesicles (fig. 7). The thin cyto-filaments can be recognized in such places.

From the cell surface many processes project which surround either partially or totally bundles of collagen fibers; the cells thus are still active phagocytotically.

Phagocytosis occurs by every cell composing the theca. But phagocytosis of collagen appears to be a generally occuring process in the post-ovulatory ovarian connective tissue compartment. Cells in the interstitium and even in the theca composed of a single cell layer around small oocytes, which appear to be fibroblasts, phagocytise collagen.

The collagen becomes morphologically indistinct within phagocytotic vesicles 3-7 days after ovulation ; there is a nearly uniform electron dense content recognisable (fig. 8). These images may be due to partial of full breakdown of the collagen fibers.

Digestion of india ink colored gelatin or collagene membranes occurs only at $\mathrm{pH}$ 4.2. AtpH 7.2 there was no sign of any digestion around the follicle and the appea-

FIG. 3. - The thick basal lamina (BL) between the follicle cells (in the center) and the theca is extensively folded. $\times 14000$.

FIG. 4. - The post-ovulatory thecal cells become siellate, forming several foot-processes. These processes isolate large bundles of collagen fibrils. Two, small, internalized, isolated phagocytotic vesicles containing few collagen fibrils are seen. $\times 30000$. 
rance remained identical to that of controles. At $\mathrm{pH} 4.2$ the digestive activity is not inhibited by the addition of EDTA.

The « Api-Zym » enzyme test system disclosed the presence of leucine and valine aminopeptidases and chymotripsin, all three giving a medium strong color reaction being evaluated as 2 on a scale of 0-4. Trypsin was negative. Acid and alkaline phosphatase were also present. The tests were positive for various esterases, such as butyric acid and caprilic acid esterases, phosphoaminidase, $\alpha$ and $\beta$ galactosidase, $\beta$ glucoronidase. Collagenase could not be demonstrated. Collagen breakdown does not occur exclusively intracellularly. In ovaries removed 17 days after ovulation near the cell surfaces many small fibrils can be found in the intercellular spaces, not to be seen at all in preovulatory follicles. One may therefore imply that some extra cellular collagen breakdown also occurs.

\section{Discussion.}

After expulsion of the mature oocytes from the trout ovary at time of ovulation ts size is greatly reduced. The size of the ovary is further reduced within the following days subsequent to the resorbtion of the spent follicles ; the size of the ovary of an adult will increase only in the middle of the next reproductive cycle after the induction of vitellogenesis.

Even though only the initial phases of the post ovulatory fate of the trout ovarian follicle was studied it can be stated that the phagocytosis and breakdown of the collagen framework may be responsible at least in part for the second ovarian size reduction.

Phagocytosis appears to be a process induced in general by fibroblasts throughout the ovarian tissue. It was observed, as described here in greatest detail, in the theca of spent follicles, but also in the theca of smatl follicles and by cells on the interstitium. It is possible thus, that a substance is produced or released at time of ovulation to which fibroblasts and their derivatives respond in general by phagocytosis. A tetrapeptide, referred to as Tuftsin, recently identified and isolated (Satoh ef al., 1972) is known to induce phagocytosis specifically by white blood cells. Certainly in the case described here such a phagocytosis inducing material remains at best hypothetical, but a secuding possibility.

FIG. 5. - 4-5 hrs after ovulation the number of collagen containing phagocytotic vesicles increases. In this case the fibrils are transveresely or obliquely sectioned. Note the large numbers of cytoplasmic fibrils of $7-8 \mathrm{~nm}$ in dimater. $\times 32000$.

FIG. 6. - Small vesicles are seen close to the phagocytotic vesicles; in a few cases they fuse (arrows) with the phagosomes. $\times 24000$.

FIG. 7. - Very large numbers of phagocytotic vesicles are found in the smooth muscle cells of the theca 4 days after ovulation. At the periphery large collagen bundles are either fully or partially surrounded by cellular footprocesses. $\times 24000$.

FIG. 8. - The outline and contrast of the collagen fibers (arrow-head) becomes less distinct in some vacuoles 5 days after ovulation. $\times 65000$. 
The collagen breakdown apparently is not due to collagenase activity because the assay was negative ; however, the presence of a collagenase inhibitor can not be excluded inspite of perfusion of the ovary with trout balanced salt solution and removal of most of the plasma. The experiments with the fixed gelatin and collagen membrane digestion tend to confirm the finding that it is not collagenase that is responsible for the breakdown of the interiorized collagen. Digestion was observed only at $\mathrm{pH} 4.2$ but not at $\mathrm{pH} 7.2$; the latter is the optimal $\mathrm{pH}$ for collagenase. Furthermore, EDTA which is known to inhibit collagenase activity, did not stop digestion of the films at $\mathrm{pH}$ 4.2. It must be recognized, however, that the serosa and follicular cells were also present in these preparations and it can not be stated that the lytic enzymes originate uniquely from the theca. The demonstration of the presence of chymotrypsin, and other peptidases with the «Api-Zym » test system points to their potential role at least in part of the breakdown of the structural framework of the theca. The participation of other lytic enzymes is certainly possible but was not tested for.

The smooth muscle cells become phagocytotically active within a few hours after ovulation. The factors necessary for the induction of this new cell activity are not understood. It is clear, however, that the cell surface becomes activated because of the extensive and rapid shape changes that follow ovulation. The smooth muscle cells which have a smooth outline and are flattened cells before ovulation transform within a few hours into stellate cells with many cellular or amoeboid processes. The collagen bundles originally isolated by the cellular micropodia are large but the phagocytosed bundles interiorized into the cytoplasm are small. In cross sectional profiles most frequently 1 to 6 collagen fibers are found per vesicle even though vesicles with larger numbers are also found. A two step process may be involved in phagocytosis ; at first, the isolation of a relatively large fiber bundle by amoeboid processes and secondarily the incorporation of a smaller number of bundles within true phagocytotic vesicles. The longitudinally sectioned vesicles indicate that very long fiber portions are interiorised into the cells. The breakdown of collagen proceeds later on within the vesicles, possible by a lysosomal system. Enzyme histochemical analysis was not yet performed but the proximity of tiny, smooth walled vesicles which occasionally fuse with the long, collagen containing vesicles suggests that in the smooth muscle cells primary lysosomes are formed which are secondarily responsible for the degradation of the collagen.

It has been known for a long time that smooth muscle cells can synthesize collagen and elastic fibers but to the knowledge of the authors this report is the first one which demonstrates a further cellular differentiation or modulation which leads to the elimination of the extracellular structural framework manufactured by the same cell.

Symposium sur la Reproduction des Poissons Paimpont, France, 19-21 septembre 1977.

Acknowledgment. - Supported in part by DGRST, Grant no 7571313.

Résumé. Au moment de l'ovulation, les cellules constituant la theca folliculi de la truite sont morphologiquement très semblables à des muscles lisses. Le comportement physiologique de ce tissu confirme sa nature de muscle lisse. Une transformation et une différenciation nouvelle apparaissent dans les quelques heures qui suivent l'ovulation : les cellules de 
la thèque commencent à phagocyter les fibres de collagène adjacentes. Des faisceaux de fibres de collagène sont d'abord partiellement entourés par des extensions cellulaires des cellules de la thèque puis de petits faisceaux sont finalement totalement englobés. Le nombre de fibres de collagène par vésicule varie de une à plusieurs. L'activité phagocytotique peuł être détectée morphologiquement jusqu'à 17 jours après l'ovulation. Après ce temps, les fibres deviennent indistinctes, ce qui indique probablement une hydrolyse. Des tests effectués avec le système « Api-zim » ef démontrant la présence de nombreuses enzymes lytiques dans les tissus ovariens post-ovulatoires sont à l'appui de ces observations morphologiques. La trypsine et la collagénase n'ont cependant pas été détectées.

\section{References}

AMSTTERDAM A., JOSEPHS R., LIEBERMAN M. E., LINDNER H. R., 1976. Organization of intermembrane particles in freez-cleaved gap-junctions of rat Graafian follicle : optical diffraction analysis. J. Cell Sci., 21, 93-106.

ELBERS P. J., VERVERGAERT P. H. J. Th., DEMEL R., 1965. Tricomplex fixation of phospholipids. J. Cell Biol., 23, 23-30.

GADDUM P., BLANDAU R. J., 1970. Froteolytic reaction of mammalian spermatozoa on gelatin membranes. Science, 170, 749-751.

JALABERT B., 1978. Production of fertilizabie oocytes from follicles of rainbow trout (Salmo gairdneri) following in vitro maturation and crulation. Ann. Biol. anim. Bioch. Biophys., 18, 461-470.

JALABERT B., SZÖLLÖSI D., 1975. In vitro maturation of trout oocytes : effect of prostaglandins on smooth muscle-like cells of the theca. Prostaglandins, 5, 765-778.

LARSEN J. H. Jr., SCHROEDER P. C., WALDO A. E., 1977. Structure and function of the amphibian follicular epithelium during ovulation. Cell Tissue Res., 181, 505-518.

MONGET D., 1975. Différences d'activité enzymatiques entre deux lignées cellulaires d'insectes : Antherea eucaplypti et Malacosoma disstria (Lepidoptera). C. R. Acad. Sci. Paris, sér. D, 281, 651-654.

NAGAI Y., LAPIERE C. M., GROSS J., 1966. Tadpole collagenase ; production and purification. Biochemistry, 5, 3123-3130.

OWERS N. O., BLANDAU R. J., 1971. Proteolytic activity of the rat and guinea pig blastocyst in vitro, 207-223. In BLANDAU R. J., The biology of the blostocyst, Chapter 11. Univ. Chicago Press.

SATOH P. S., CONSTANTINOPOULOS A., NISHIOKA K., NAJJAR V., 1972. Tuftsin : threonyllysyl-prolyl-arginine, the phagocylosis stimulating messenger of the carrier cytophilic $\gamma$-globulin leukokinin, 403-408. In MEIENHOFER J., Chem. Niol. Pept. ; Proc. 3rd am. Pept. Symp.

SZOLLÖSI D., JALABERT B., 1974. La thèque du follicule ovarien de la truite. J. Microscop., 20, 92a. 